Louisiana State University

LSU Digital Commons

4-1-2005

\title{
Differential DNA binding and protection by dimeric and dodecameric forms of the ferritin homolog Dps from Deinococcus radiodurans
}

Anne Grove

Louisiana State University

Steven P. Wilkinson

Louisiana State University

Follow this and additional works at: https://digitalcommons.Isu.edu/biosci_pubs

\section{Recommended Citation}

Grove, A., \& Wilkinson, S. (2005). Differential DNA binding and protection by dimeric and dodecameric forms of the ferritin homolog Dps from Deinococcus radiodurans. Journal of Molecular Biology, 347 (3), 495-508. https://doi.org/10.1016/j.jmb.2005.01.055 


\section{Differential DNA Binding and Protection by Dimeric and Dodecameric forms of the Ferritin Homolog Dps from Deinococcus radiodurans}

\section{Anne Grove ${ }^{\star}$ and Steven P. Wilkinson}

Department of Biological

Sciences, Louisiana State University, Baton Rouge LA 70803, USA

\begin{abstract}
Bacterial iron storage proteins such as ferritin serve as intracellular iron reserves. Members of the DNA protection during starvation (Dps) family of proteins are structurally related to ferritins, and their function is to protect the genome from iron-induced free radical damage. Some members of the Dps family bind DNA and are thought to do so only as fully assembled dodecamers. We present the cloning and characterization of a Dps homolog encoded by the radiation-resistant eubacterium Deinococcus radiodurans and show that DNA binding does not require its assembly into a dodecamer. D. radiodurans Dps-1, the product of gene DR2263, adopts a stably folded conformation, as demonstrated by circular dichroism spectroscopy, and undergoes a transition to a disordered state with a melting temperature of $69.2( \pm 0.1)^{\circ} \mathrm{C}$. While a dimeric form of Dps-1 is observed under low-salt conditions, a dodecameric assembly is highly favored at higher concentrations of salt. Both oligomeric forms of Dps-1 exhibit ferroxidase activity, and Fe(II) oxidation/mineralization is seen for dodecameric Dps-1. Notably, addition of $\mathrm{Ca}^{2+}$ (to millimolar concentrations) to dodecameric Dps-1 can result in the reduction of bound Fe(III). Dimeric Dps-1 protects DNA from both hydroxyl radical cleavage and from DNase I-mediated cleavage; however, dodecameric Dps-1 is unable to provide efficient protection against hydroxyl radical-mediated DNA cleavage. While dodecameric Dps-1 does bind DNA, resulting in formation of large aggregates, cooperative DNA binding by dimeric Dps-1 leads to formation of protein-DNA complexes of finite stoichiometry.
\end{abstract}

(C) 2005 Elsevier Ltd. All rights reserved.

Keywords: ferroxidase; iron mineralization; iron storage; DNA protection; DNA binding

\section{Introduction}

During aerobic growth, reactive oxygen species are generated that have the potential to damage proteins, membrane lipids and DNA. For example, reaction of $\mathrm{H}_{2} \mathrm{O}_{2}$ with transition metals such as ferrous iron can result in the formation of highly reactive hydroxyl radicals through the Fenton reaction, ${ }^{1}$ and microorganisms have developed an array of inducible mechanisms for scavenging such reactive species, including superoxide dismutases, catalases and peroxidases. ${ }^{2}$ Primarily studied in Escherichia coli, another key component of the

Abbreviations used: Dps, DNA protection during starvation protein; $\mathrm{CD}$, circular dichroism.

E-mail address of the corresponding author: agrove@lsu.edu response to oxidative stress is the non-specific DNA-binding, DNA protection during starvation (Dps) protein. E. coli Dps was shown to exert its protective effects by a combination of physical association with the DNA and by its ability to chelate ferrous iron. $^{3-6}$ The occurrence of oxidative radicals is greatest during the stationary phase of bacterial growth; accordingly, Dps expression was shown to be induced during stationary phase and in response to nutrient deprivation, and the protein was shown to form toroidal assemblies with the genomic DNA. ${ }^{7-9}$

Iron is generally stored in ferritins that sequester the metal in a non-toxic, yet bioavailable form. Ferritins are typically oligomers of 24 subunits that assemble into a spherical shell. ${ }^{10}$ Each subunit adopts a four-helix bundle conformation with a fifth short helix lying at an angle relative to the axis of the four-helix bundle. ${ }^{11,12}$ These molecules carry 
a highly conserved ferroxidase center within the four-helix bundle that allows uptake of $\mathrm{Fe}^{2+}$ in the presence of molecular oxygen. In contrast, bacterial proteins belonging to the Dps family, which have also been shown to exhibit ferroxidase activity, assemble into dodecamers. ${ }^{13-17}$ Each subunit assembles into a four-helix bundle; however, the iron-binding site is not within the four-helix bundle but generated by subunits related by 2-fold symmetry.

While the ferroxidase center is highly conserved among Dps proteins, an N-terminal tail of variable length that contains several lysine residues extends from the four-helix bundle core into the solvent; this $\mathrm{N}$-terminal tail has been proposed to participate in stabilization of the complex with DNA. ${ }^{14}$ Consistent with this notion, proteins whose N-terminal tail is missing or truncated, as seen for Dps homologs such as Hp-NAP from Helicobacter pylori or Dps from Agrobacterium tumefaciens, fail to bind DNA. ${ }^{18,19}$ Electrostatic considerations of E. coli Dps suggested that it is the dodecameric form that binds DNA, as reported for the Mycobacterium smegmatis-encoded Dps homolog. ${ }^{14,20}$

The mesophilic eubacterium Deinococcus radiodurans encodes two proteins that are predicted to belong to the Dps family of proteins. $D$. radiodurans is best known for its unusual resistance to DNAdamaging agents, such as ionizing radiation and desiccation, both conditions that would be characterized by the presence of oxidative radicals. ${ }^{21,22}$ Both Dps homologs are characterized by unusually long N-terminal extensions, predicting their ability to bind DNA in addition to exhibiting ferroxidase activity. The Dps homolog most closely related to E. coli Dps (designated Dps-1, corresponding to DR2263) is encoded on chromosome 1, while the other (Dps-2, the product of DRB0092) is encoded on megaplasmid MP1. ${ }^{23}$ We show here that dodecameric and dimeric Dps-1 bind DNA, and that both oligomeric forms exhibit ferroxidase activity. Notably, addition of $\mathrm{Ca}^{2+}$ (to millimolar concentrations) to iron-loaded, dodecameric Dps-1 can lead to a reduction of absorbing Fe(III) species.

\section{Results}

\section{Sequence conservation predicts ferroxidase activity and DNA binding by Dps-1}

Pairwise alignment of Dps-1 with E. coli Dps or Listeria ferritin shows $26 \%$ and $32 \%$ identity, respectively, excluding the $\mathrm{N}$-terminal extension, suggesting conservation of the four-helix bundle fold (Figures 1 and 2(c)). A multiple sequence alignment reveals complete conservation of the ferroxidase center, assembled from two histidine residues (H83 and H94) from one subunit, and an aspartate residue (D109) and a glutamate residue (E113) from another. The conserved aspartate residue at position 98 corresponds to D47 of Listeria ferritin, where it is considered to compensate for the positive charge of iron. ${ }^{15}$ In assembling the dodecamer, 3-fold interactions generate hydrophilic pores at the 3 -fold axes that are lined with acidic side-chains. These pores provide the pathway for entry of iron into the central cavity. ${ }^{14,15}$ While D174 and D182 correspond to two of the three residues generating the strong negative surface potential in Listeria ferritin, the third aspartate residue is replaced with a proline residue (P178) in Dps-1. Calculation of the electrostatic potential of E. coli Dps suggested that the dodecamer is the DNAbinding species, and that the lysine-containing $\mathrm{N}$-terminal tail is required for DNA binding. ${ }^{14}$ The $\mathrm{N}$-terminal extension is considerably longer in Dps-1 and contains a total of seven lysine residues.

\section{Oligomerization and secondary structure and stability of Dps-1}

The gene encoding Dps-1 was amplified from $D$. radiodurans $\mathrm{RI}$ and expressed in E. coli (Figure 2 ). Two distinct oligomeric forms were isolated, shown to correspond to a dimer and a dodecamer: Purification under reducing conditions resulted in a fraction of the Dps-1 protein to elute from heparin-agarose at low concentrations of salt. However, it was noted that omission of $\beta$-mercaptoethanol from the buffers caused Dps-1, which contains a single cysteine residue, to elute from heparin-agarose exclusively at higher concentrations of salt, potentially corresponding to enhanced DNA-binding by an oligomeric assembly. Omission of $\beta$-mercaptoethanol from the SDSPAGE loading buffer resulted in primarily monomeric Dps-1, with only trace amounts of dimer, suggesting the absence of disulfide-linked monomers (Figure 2(d)). Assuming conservation of the four-helix bundle fold, the single cysteine residue would be located at the $C$ terminus of helix $C$, on the opposite face of the four-helix bundle relative to the conserved ferroxidase center and in the vicinity of negatively charged residues forming the entry path for iron (Figures 1 and 2(c)). Glutaraldehydemediated crosslinking of Dps-1 obtained under reducing conditions in buffer containing $50 \mathrm{mM}$ $\mathrm{NaCl}$ yielded dimers as the predominant species, with no indication of higher-order oligomeric assemblies (Figure 2(a)). Combined with the limited dimerization of oxidized Dps-1, this suggests that the crosslinked dimer corresponds to the symmetry-related monomers that form the ferroxidase

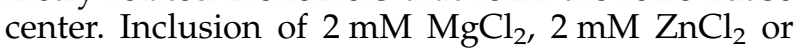
$500 \mathrm{mM} \mathrm{NaCl}$ in the reaction resulted in the formation of all possible even-numbered oligomeric assemblies, up to a dodecamer (Figure 2(b) and data not shown). This is in contrast to E. coli Dps, which was reported to form predominantly trimers and dodecamers after crosslinking with glutaraldehyde. ${ }^{14}$ Inclusion of DNA in the reactions did not affect oligomerization patterns, regardless of the concentration of salt (data not shown). These data show the ability to crosslink different oligomeric assemblies (Figure 2(b)), indicating that the absence 


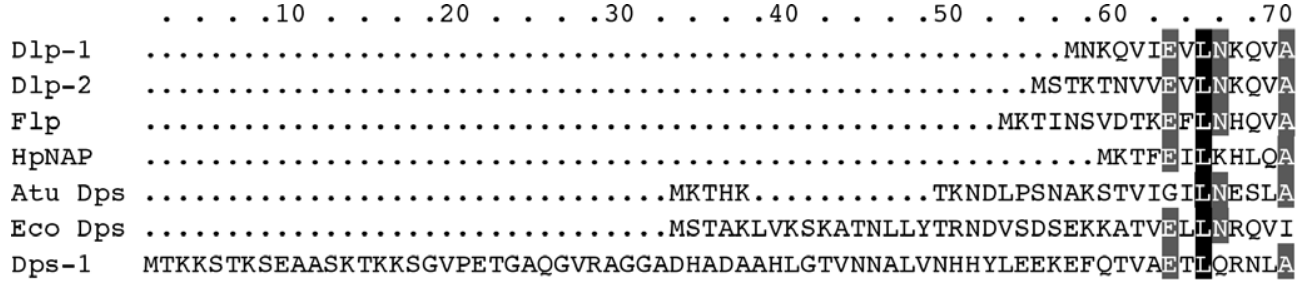

AAAAAAAAAA
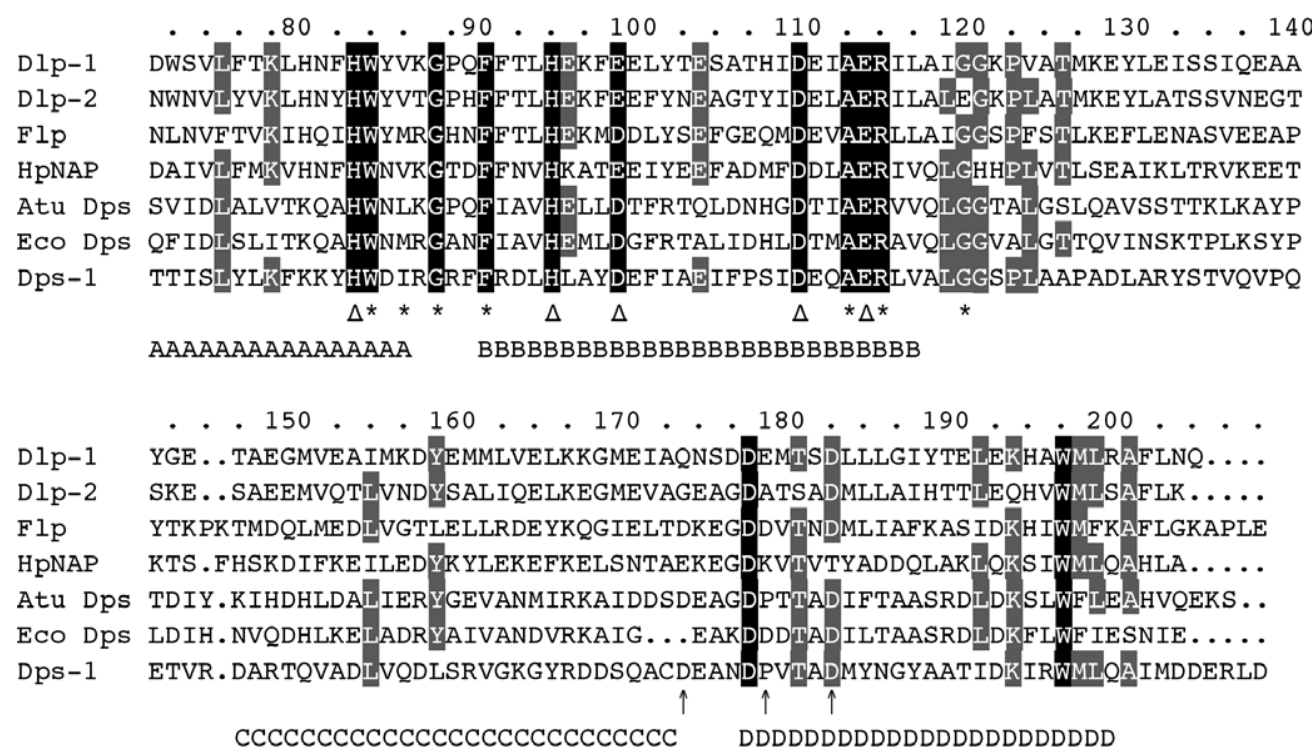

Figure 1. Alignment of Dps homologs. Sequences are numbered on the basis of the D. radiodurans Dps-1 sequence. A shaded background identifies conserved residues. Helical segments from the structure of Listeria innocua ferritin (Flp) are identified by the letters A, B, C and D below the alignment. Asterisks and triangles denote the so-called DNAbinding signature, with triangles identifying residues primarily involved in coordinating iron. Arrows point to residues from the Flp structure that provide the pathway for entry of iron. Dlp-1, Bacillus anthracis Dps homolog, NP_653511; Dlp2, B. anthracis Dps homolog, NP_655877; Flp, L. innocua ferritin, P80725; HpNAP, H. pylori neutrophil-activating protein, P43313; Atu Dps, A.tumefaciens Dps, NP_533149; Eco Dps, E. coli Dps, P27430; Dps-1, Dps homolog encoded by D. radiodurans, DR2263.

of higher-order oligomeric assemblies seen when crosslinking Dps-1 in low-salt buffer (Figure 2(a)) is not likely to be caused by inefficient crosslinking of oligomers other than the identified dimer.

Crosslinking of Dps-1 purified under nonreducing conditions revealed a high molecular mass assembly whose migration would be consistent with a dodecamer (Figure 2(d), lane 3). We note that the essentially quantitative crosslinking of the dodecameric species excludes the existence of lower oligomeric assemblies in solution; if such species existed and merely failed to crosslink, a significant proportion of protein should appear monomeric following SDS-PAGE. This (uncrosslinked) dodecameric species also migrated in native PAGE as a single band with a molecular mass greater than that of bovine serum albumin (BSA, whose pI of 5.4 is similar to the theoretical pI of Dps-1 of 5.3), consistent with the absence of lower molecular mass oligomers (data not shown). Consistent with these observations, and in accord with expectations from sequence alignments, the structure of Dps-1, solved at $2 \AA$ resolution, reveals a dodecameric assembly (Y.-H. Lee, personal communication).

Exposure to reducing agents, such as $\beta$-mercaptoethanol or dithionite, did not lead to dissociation of the dodecamer (not shown), and dilution of dodecameric Dps-1 (which eluted from the heparin column at $\sim 600 \mathrm{mM} \mathrm{KCl}$ ) into a low-salt $(50 \mathrm{mM}$ $\mathrm{KCl}$ ) buffer caused its immediate precipitation, suggesting that assembly of the dodecamer is effectively irreversible. Incubation for 20 hours at $\mathrm{pH} \sim 2(0.01 \mathrm{mM} \mathrm{HCl})$ retained the high molecular mass crosslinked species (Figure 2(d), lane 5), while incubation for 20 hours with $0.1 \mathrm{mM} \mathrm{HCl}(\mathrm{pH} \sim 1)$ resulted in the formation of both dimeric crosslinked species and in monomeric species that failed to crosslink (Figure 2(d), lane 6). This behavior is similar to the acid-induced unfolding reported for Listeria ferritin. ${ }^{24}$ Evidently, Dps-1 oligomers do not exist in a dynamic equilibrium; rather, Dps-1 can exist as a dimer at low salt, while assembly of a very stable dodecamer is favored at higher concentrations of salt. On the basis of these observations, we assayed dimeric Dps-1 in buffers containing up 
(a)

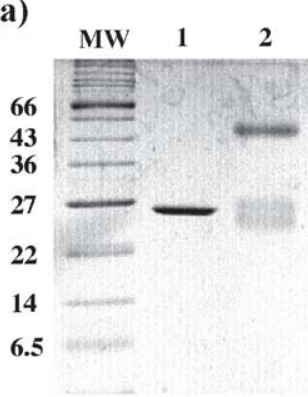

(b)

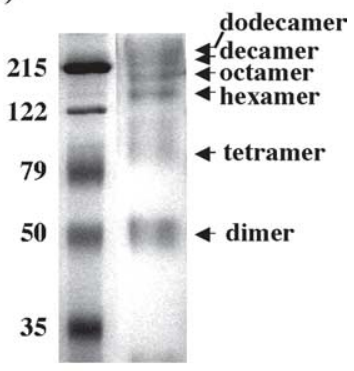

(c)

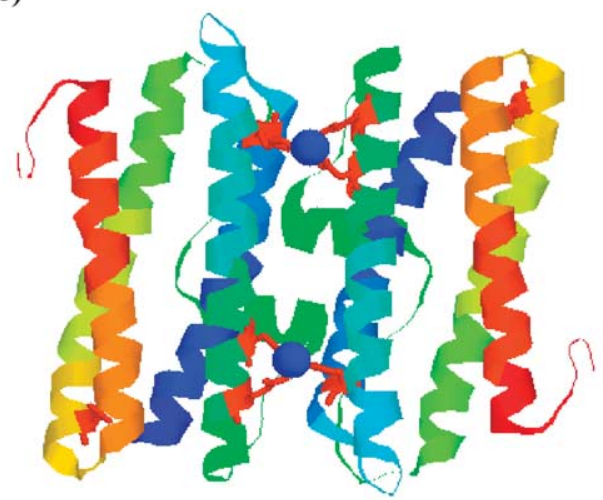

(d)

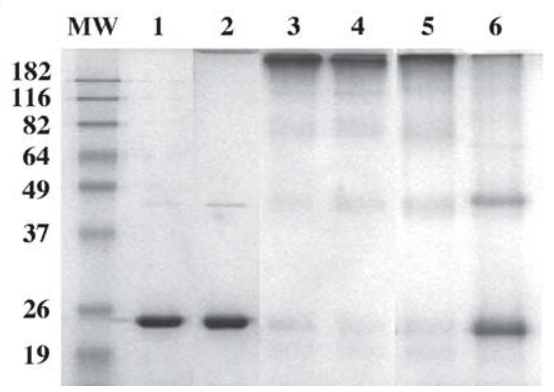

Figure 2. Purified Dps-1. (a) An SDS-17\% PAGE gel stained with Coomassie brilliant blue showing purified Dps-1 obtained under reducing conditions (lane 1). Lane 2 contains $1 \mu \mathrm{g}$ of Dps crosslinked with $0.1 \%(\mathrm{v} / \mathrm{v})$ glutaraldehyde for 30 minutes in the presence of $50 \mathrm{mM}$ $\mathrm{NaCl}$. Molecular mass markers are identified at the left (in $\mathrm{kDa}$ ). (b) Crosslinking of $2.5 \mu \mathrm{g}$ of Dps-1 in the presence of $500 \mathrm{mM} \mathrm{NaCl}$ (SDS-8\% PAGE gel). Oligomeric assemblies are indicated at the right. (c) Two symmetry-related subunits of Listeria ferritin (PDB 1QGH) showing the dimeric interface forming the ferroxidase center. Iron atoms are shown as blue spheres. Residues H31, H43, D58 and E62 that coordinate iron are indicated (red). T120 at the $\mathrm{C}$ terminus of helix $\mathrm{C}$ corresponds to the position of the single cysteine residue in D. radiodurans Dps- 1 . Helices A, B, C and D (Figure 1) are colored dark to light blue, blue to green, green to yellow and orange to red, respectively, from the $\mathrm{N}$ terminus to the $\mathrm{C}$ terminus. Illustration generated with RasMol. (d) An SDS$12 \%$ PAGE gel stained with Coomassie brilliant blue showing Dps-1 purified under non-reducing conditions (lane 1). Lane 2 contains Dps-1 electrophoresed without $\beta$-mercaptoethanol in the gel loading buffer. Lanes 3-6 contain $2.5 \mu \mathrm{g}$ of Dps-1 crosslinked with $0.1 \%(\mathrm{v} / \mathrm{v})$ glutaraldehyde in the presence of $500 \mathrm{mM} \mathrm{NaCl}$, with lane 4 showing crosslinking after addition of $2 \mathrm{mM} \mathrm{ZnCl}_{2}$; electrophoresis on $6 \%$ polyacrylamide gels shows a to $100 \mathrm{mM}$ monovalent salt (to prevent its further oligomerization), while dodecameric Dps-1 was assayed in buffers with higher concentrations of salt (to prevent its precipitation).

The secondary structure of Dps-1 was analyzed optically using circular dichroism (CD) spectroscopy. The far-UV CD spectrum of dodecameric Dps at $25^{\circ} \mathrm{C}$ is characterized by ellipticity minima at $208 \mathrm{~nm}$ and $222 \mathrm{~nm}$, reflecting a high $\alpha$-helical content, consistent with structural data from other Dps homologs (Figure 3(a)). No detectable difference was observed in the CD spectra of apo-Dps-1 or Fe-loaded Dps-1 (where the prefix apo refers to Dps-1 without a mineralized iron core; data not shown). Whereas the relative intensities of the negative minima at $208 \mathrm{~nm}$ and $222 \mathrm{~nm}$ were similar in magnitude under these conditions, wavelength scans at higher concentrations of Dps1 resulted in a significant reduction in the intensity of the negative minimum at $208 \mathrm{~nm}$, relative to the negative peak at $222 \mathrm{~nm}$ (data not shown). It is likely that this distortion of the CD spectrum at higher concentrations of protein is the result of differential absorption flattening, a phenomenon witnessed for membrane proteins. ${ }^{25}$ This effect results from a non-uniform, closely packed distribution of protein chromophores in the sample solution, which reduces protein absorption. The flattening of the absorption of left and right circularly polarized light will differ in chiral protein samples, and will therefore distort the $\mathrm{CD}$ signal. The flattening effect on the CD signal is proportional to absorbance, and is greatest at wavelengths matching protein absorption peaks. Experimentally, absorption flattening has been shown to lead to significant distortion in the relative peak intensities at $208 \mathrm{~nm}$ and $222 \mathrm{~nm} .{ }^{26}$ The absorption flattening recorded for Dps-1 is consistent with its assembly into ordered oligomeric structures.

Ellipticity measurements at five wavelengths spanning the negative ellipticity minimum of $222 \mathrm{~nm}$ were recorded over the temperature range of $25-100{ }^{\circ} \mathrm{C}$ and were fit to a modified van't Hoff equation for a two-state unfolding equilibrium (Figure 3(b)). The CD melting curve reveals a sharp, single transition from the native to a definitive denatured conformation with a calculated $T_{\mathrm{m}}$ of $69.2( \pm 0.1)^{\circ} \mathrm{C}$, suggesting a two-state unfolding equilibrium for Dps-1. The apparent van't Hoff enthalpy of Dps-1 denaturation, $\Delta H_{\mathrm{vH}}$, was determined to be $116.2( \pm 0.8) \mathrm{kcal} / \mathrm{mol}$, though the thermal Dps-1 unfolding transition did not prove reversible under the conditions used.

migration of the crosslinked species consistent with a dodecamer (not shown). Samples in lanes 5 and 6 were incubated for 20 hours with $0.01 \mathrm{M}$ or $0.1 \mathrm{M} \mathrm{HCl}$, respectively, following which they were neutralized with bicine ( $\mathrm{pH} 8.5)$ and crosslinked. 
(a)

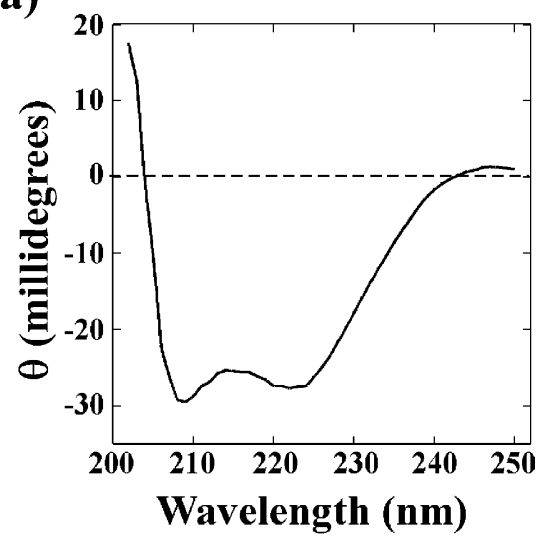

(b)

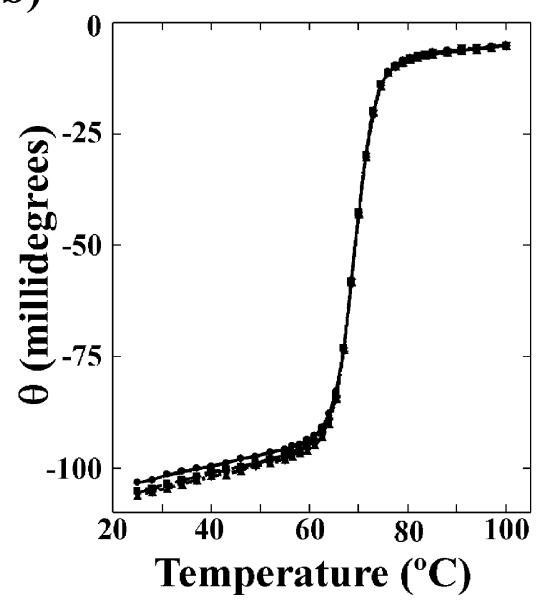

Figure 3. CD spectral analysis of HucR. (a) Far-UV CD spectrum of dodecameric Dps-1 at $25^{\circ} \mathrm{C}$. Ellipticity measurements are expressed in machine units (millidegrees). (b) Thermal unfolding transition of Dps- 1 . Ellipticity measurements were collected over the temperature range of $25-100{ }^{\circ} \mathrm{C}$ at five wavelengths spanning the negative ellipticity maximum characteristic of

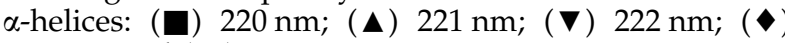
$223 \mathrm{~nm}$; and (O) $224 \mathrm{~nm}$.

\section{Iron incorporation by Dps-1}

Absorbance spectra of purified dodecameric Dps-1 revealed its partitioning into three populations (Figure 4(a)): populations that bound more strongly to heparin-agarose were characterized by a significant absorbance above $300 \mathrm{~nm}$, suggesting the presence of a mineralized iron core, while a third population exhibited only little absorbance at $300-400 \mathrm{~nm}$. This observation is reminiscent of the previously reported all-or-none distribution of iron among ferritin molecules. ${ }^{27} \mathrm{We}$ note that a distinguishable peak at $280 \mathrm{~nm}$ is not seen for dodecameric Dps-1, which is characterized by a more defined absorbance peak at $\sim 360 \mathrm{~nm}$ (Figure 4(a), broken line), rather a continuous rise in absorbance is seen at $280-250 \mathrm{~nm}$, suggesting the presence of bound $\mathrm{Fe}(\mathrm{III})$.

Treatment with bipyridyl and dithionite reduces (a)

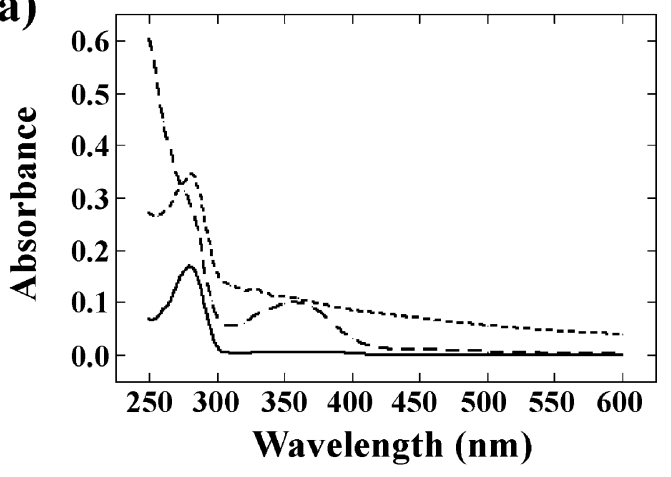

(b)
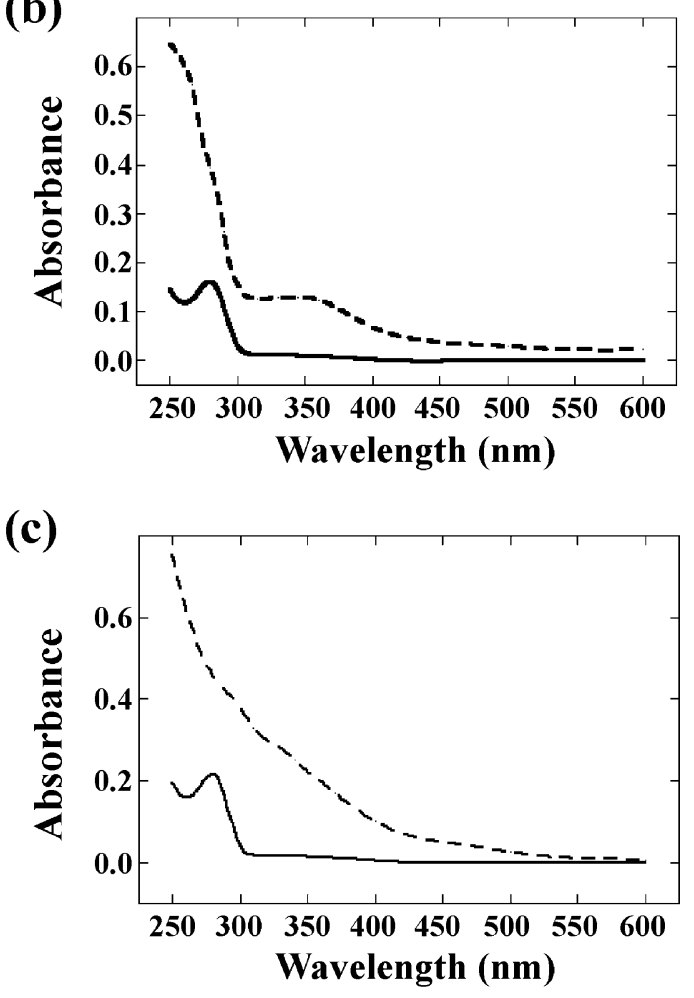

(d)

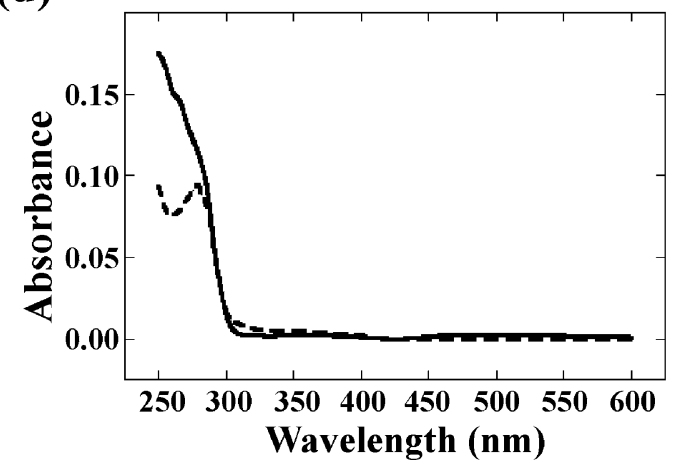

Figure 4. Iron binding by Dps-1. (a) Absorbance spectra of $0.2 \mathrm{mg} / \mathrm{ml}$ of dodecameric Dps-1 purified in the apo form (continuous line) or with an iron core (broken and dotted lines). (b) Absorbance of $0.2 \mathrm{mg} / \mathrm{ml}$ of corecontaining Dps-1 before (broken line) and after (continuous line) treatment with dithionite and bipyridyl. (c) Absorbance of $0.25 \mathrm{mg} / \mathrm{ml}$ of apo-Dps-1 before (continuous line) and after (broken line) ferroxidation using a $5: 1$ molar ratio of Fe to monomer. (d) Absorbance spectrum of dimeric Dps-1, equilibrated in air. 
the absorbance, generating apo-Dps-1 (Figure 4(b)). Evidently, dithionite causes iron reduction and release, as seen in classical ferritins and in other Dps proteins. ${ }^{6,10,19}$ In contrast, iron-loaded Dps- 1 is characterized by a strong absorbance above $300 \mathrm{~nm}$, indicating oxidative deposition of iron within the Dps-1 core (Figure 4(c)). To monitor the time-course of iron reduction, iron-loaded Dps-1 was treated with bipyridyl and dithionite, and formation of the Fe(II)-2,2'-bipyridyl complex was monitored at $520 \mathrm{~nm}$ (Figure 5). The time-course is biphasic, with rate constants of $7.8( \pm 0.9) \times 10^{-2} \mathrm{~s}^{-1}$ and $3.9( \pm 0.1) \times 10^{-3} \mathrm{~s}^{-1}$, comparable to the rate constants for E. coli Dps of $14.2 \times 10^{-2} \mathrm{~s}^{-1}$ and $4.6 \times 10^{-3} \mathrm{~s}^{-1}$ at $\mathrm{pH}$ 6.5. ${ }^{6}$ A wavelength scan of dimeric Dps-1 equilibrated in air shows the expected absence of absorbance above $300 \mathrm{~nm}$, as seen for dodecameric apo-Dps-1 (Figure 4(d)). As for dodecameric Dps-1, two populations of dimeric Dps-1 may be identified that differ in their absorbance properties at $280-250 \mathrm{~nm}$. No mobilizable iron is present, and treatment with dithionite and bipyridyl does not lead to formation of an $\mathrm{Fe}(\mathrm{II})-2,2^{\prime}$-bipyridyl complex (Figure 5).

The presence of $\mathrm{Ca}^{2+}$ affects the Fe(III) absorbance (Figure 6(a)). While the addition of $\mathrm{Ca}^{2+}$ has no effect on the absorbance spectrum of apo-Dps-1 or on that of Dps-1 characterized by a more defined absorbance peak at $360 \mathrm{~nm}$ (data not shown), Dps-1 characterized by a gradually decreasing absorbance from $300-600 \mathrm{~nm}$ is modulated by $\mathrm{Ca}^{2+}$. Remarkably, the presence of $\mathrm{Ca}^{2+}$ leads to loss of absorbance from the mineralized iron core, and it reduces the absorbance at lower wavelengths more efficiently than does the presence of dithionite. This is significant in light of the recently published structure of a Dps homolog from Streptococcus suis, in which two aspartate residues that otherwise participate in forming the ferroxidase center have undergone a conformational change that allows them instead to coordinate a calcium ion. ${ }^{28}$ Perhaps coordination of iron or calcium ions is also mutually exclusive in Dps-1. The time-course of iron reduction was measured as a function of $\left[\mathrm{Ca}^{2+}\right]$, showing a rapid decrease in the absorbance at $380 \mathrm{~nm}$ upon addition of millimolar $\mathrm{Ca}^{2+}$ (Figure 6(b)). Further evidence for separate binding sites for iron and calcium ions is suggested by the observation that the addition of $\mathrm{Zn}^{2+}$, previously shown to inhibit ferroxidase activity of both ferritin and Dps homologs by binding at the ferroxidase center, ${ }^{29}$ does not lead to reduction of $\mathrm{Fe}(\mathrm{III})$ absorbance at $380 \mathrm{~nm}$ (not shown). On exposure to air, absorbance at lower wavelengths $(<310 \mathrm{~nm})$ is recovered slowly for $\mathrm{Ca}^{2+}$-bound Dps-1, but no absorbance corresponding to mineralization is seen, suggesting that $\mathrm{Ca}^{2+}$ prevents the movement of iron to the protein core (not shown).

The absorbance of Dps-1 was measured at $310 \mathrm{~nm}$ after addition of $\mathrm{Fe}(\mathrm{II})$ to monitor the timedependent conversion of $\mathrm{Fe}(\mathrm{II})$ to $\mathrm{Fe}(\mathrm{III})$ in the presence of molecular oxygen (air). As shown in Figure 6(c), ferroxidase activity of dodecameric

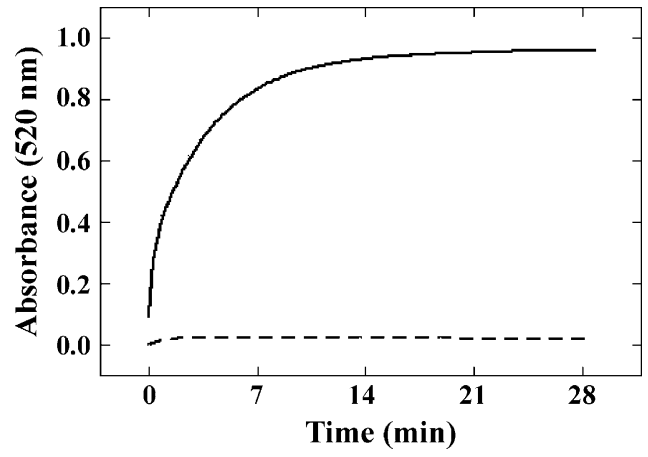

Figure 5. Kinetics of iron reduction by dithionite from iron-loaded dodecameric Dps-1. Absorbance at $520 \mathrm{~nm}$ corresponds to the absorbance maximum of the Fe(II)-22 '-bipyridyl complex. ${ }^{19}$ The reaction corresponding to the dotted line contained dimeric Dps-1.

Dps-1 is evident from the increase in absorbance upon addition of five $\mathrm{Fe}$ (II) per monomer compared to oxidation of $\mathrm{Fe}(\mathrm{II})$ by molecular oxygen in the absence of Dps-1. However, rates are slow compared to other Dps homologs; secondly, the presence of $\mathrm{Ca}^{2+}$ affects both the initial rates of ferroxidation and the shape of the progress curves. Initial rates are particularly slow if $\mathrm{Fe}(\mathrm{II})$ is added to protein purified in its apo form (corresponding to Figure 4(a), continuous line) or to $\mathrm{Ca}^{2+}$-sensitive core-containing Dps-1 (seen in Figure 4(a), dotted line) within minutes after addition of $\mathrm{Ca}^{2+}$ (Figure 6(c), broken line), suggesting that bound $\mathrm{Ca}^{2+}$ has induced conformational changes in the protein that attenuate the rate of ferroxidation or transport of iron to the protein core. The progress curve appears largely hyperbolic. Faster initial rates are seen if $\mathrm{Fe}$ (II) is added after a prolonged incubation (several hours) following exposure of core-containing Dps-1 to $\mathrm{Ca}^{2+}$ (continuous line), perhaps corresponding to a slow conformational change at the ferroxidase center or elsewhere in the protein associated with the replacement of bound $\mathrm{Ca}^{2+}$ with $\mathrm{Fe}^{2+}$. The progress curves recorded after prolonged incubation of $\mathrm{Ca}^{2+}$-bound protein do not appear hyperbolic but exhibit a second fast phase preceding the final plateau. Such progress curves are seen for core-containing protein. We interpret these data as follows: If $\mathrm{Ca}^{2+}$ binds Dps-1 only at the ferroxidase center to affect ferroxidation at this site, then its replacement with Fe(II) should be complete at a stoichiometry of Dps-1 monomer to $\mathrm{Fe}(\mathrm{II})$ of $1: 1$, following which, maximal rates should be seen. However, this is not observed; even after ferroxidation of stoichiometric amounts of $\mathrm{Fe}(\mathrm{II})$, rates remain slow (Figure 6(c), broken line), unless the protein is incubated with both calcium and iron for several hours (continuous line). This suggests that $\mathrm{Ca}^{2+}$ affects ferroxidation at the ferroxidase center, and is rate-limiting for another step, perhaps transport of $\mathrm{Fe}$ (II) to the protein core.

Ferroxidase activity was recorded for Dps-1 
(a)

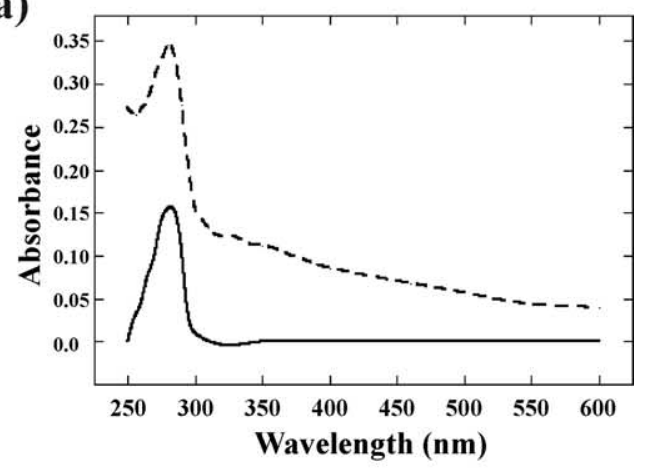

(b)

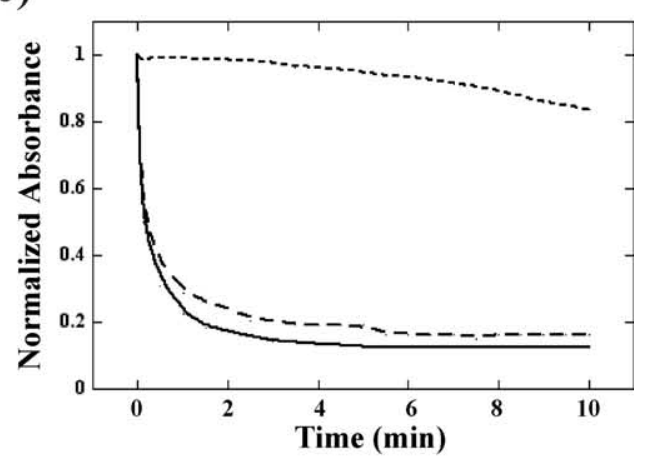

(c)

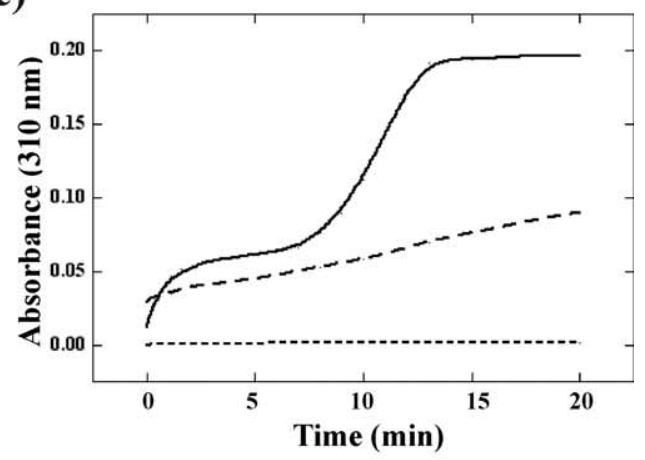

(d)

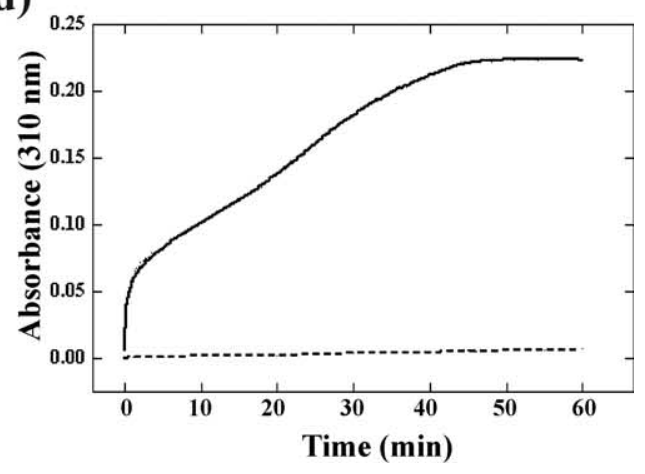

Figure 6. Ferroxidase activity of Dps-1. (a) Absorbance spectra of $0.2 \mathrm{mg} / \mathrm{ml}$ of dodecameric Dps-1 before (broken line) or after incubation with $5 \mathrm{mM} \mathrm{CaCl}$ for ten minutes. (b) Absorbance at $380 \mathrm{~nm}$ of $0.2 \mathrm{mg} / \mathrm{ml}$ of Dps-1, normalized to the absorbance at time zero, after addition of $1 \mathrm{mM} \mathrm{CaCl}$ (dotted line), $2.5 \mathrm{mM} \mathrm{CaCl} 2$ (broken line), or $5 \mathrm{mM} \mathrm{CaCl}_{2}$ (continuous line). The initial absorbance was 0.10 . (c) Kinetics of $\mathrm{Fe}(\mathrm{II})$ oxidation in the presence of $0.2 \mathrm{mg} / \mathrm{ml}$ of Dps-1 and molecular oxygen purified under reducing conditions (Figure 6(d)), consistent with dimeric Dps-1 containing the ferroxidase center. Progress curves are largely biphasic, with an initial fast phase. Notably, no second fast phase is seen. As expected, $\mathrm{Zn}^{2+}$ is an effective inhibitor of the ferroxidase activity (not shown). Taken together, these data suggest $\mathrm{Ca}^{2+}$. induced conformational changes affecting two areas of the protein: (1) $\mathrm{Ca}^{2+}$-bound Dps-1 exhibits slow initial ferroxidation rates, suggesting that $\mathrm{Ca}^{2+}$ bound at the ferroxidase center, while Dps- 1 with iron bound at the ferroxidase center exhibits faster initial rates, suggesting conformational changes at the ferroxidase center to accommodate either bound $\mathrm{Ca}^{2+}$ or $\mathrm{Fe}^{2+}$ (Figure 6(c) and (d)). (2) Conformational changes occur elsewhere upon binding of $\mathrm{Ca}^{2+}$ that permit only a slow $\mathrm{Fe}(\mathrm{II})$ oxidation at the ferroxidase center, while the absence of $\mathrm{Ca}^{2+}$ or a prolonged pre-incubation of Dps-1 allows the nucleation of a mineralized iron core that supports the direct surface oxidation of $\mathrm{Fe}(\mathrm{II})$, leading to a second fast phase (Figure 6(c)).

\section{DNA binding and protection by Dps-1}

The binding of Dps-1 to DNA was analyzed using agarose gel electrophoresis (Figure 7). With dimeric Dps-1, a gradual conversion to a Dps-1-DNA complex is observed, with complete complex formation at $4.3 \mu \mathrm{M}$ dimeric Dps-1 (lane 5). Complex formation is modestly salt-dependent, with about $50 \%$ complex formed by $4.3 \mu \mathrm{M}$ Dps-1 in the presence of $500 \mathrm{mM} \mathrm{NaCl}$ (Figure 7(a), lane 7). The bimodal distribution, particularly pronounced at higher concentrations of salt, reflecting Dps-1 binding preferentially to DNA already occupied by protein, suggests cooperative binding. ${ }^{30}$ The efficiency of binding to supercoiled (lane 5) or linear DNA (lane 8) is equivalent, suggesting no apparent preference for either topological form. Two additional features of this experiment are worthy of note: DNA binding was performed with Dps-1 that yields dimeric product following crosslinking with glutaraldehyde $(2.2 \mu \mathrm{M}$ dimeric Dps-1 corresponding to $0.1 \mathrm{mg} / \mathrm{ml}$, the final concentration used in Figure 2(a)), indicating that formation of the dodecameric assembly is unnecessary for DNA binding by Dps-1. Secondly, E. coli Dps and M. smegmatis Dps, which were both suggested to bind DNA only as dodecameric assemblies, were reported to give rise only to complexes that do not enter the gel. ${ }^{4,19}$ The observed formation of Dps-1DNA complexes of distinct mobility at saturation

(air): continuous line, $5: 1$ molar excess of Fe(II) per Dps-1 monomer, recorded after incubation of Dps-1 with $5 \mathrm{mM}$ $\mathrm{CaCl}_{2}$ for eight hours; broken line, progress curve recorded after incubation with $5 \mathrm{mM} \mathrm{CaCl}$ for ten minutes; a final absorbance of $\sim 0.2$ was reached after $\sim 50$ minutes. Dotted line, auto-oxidation in the absence of Dps-1. (d) Progress curve of iron oxidation by dimeric Dps-1 (5:1 molar excess of $\mathrm{Fe}(\mathrm{II})$; continuous line). Dotted line, auto-oxidation in the absence of Dps-1. 
(a)

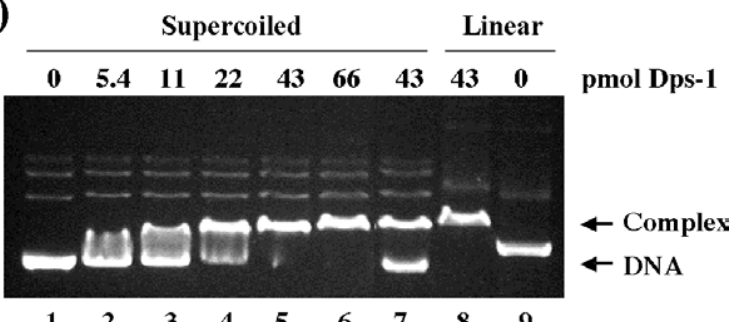

(b)

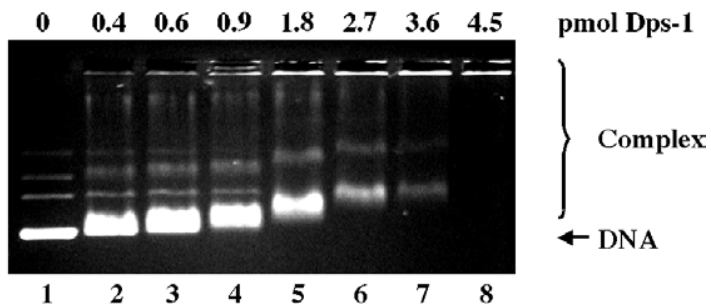

(c)

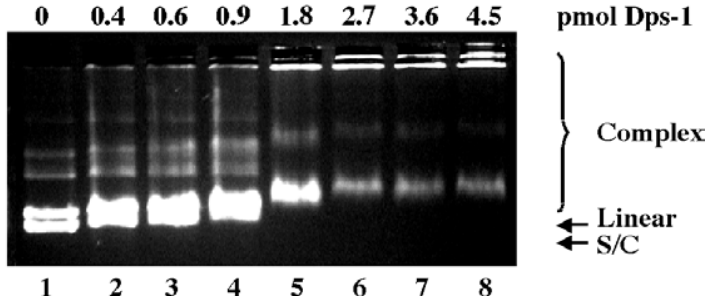

Figure 7. DNA binding by Dps-1. (a) Agarose gel electrophoresis of dimeric Dps-1 bound to supercoiled (lanes 1-7) or linear (lanes 8 and 9) DNA. Reaction conditions are as described in Materials and Methods, except that the reaction in lane 7 contained $500 \mathrm{mM} \mathrm{NaCl}$ Concentrations of dimeric Dps-1 are indicated above the panel. (b) Agarose gel electrophoresis of dodecameric Dps-1 bound to supercoiled DNA. Concentrations of dodecameric Dps-1 are indicated above the panel (corresponding to iron-containing, purified Dps-1 seen in Figure 4(a), dotted line). (c) Agarose gel electrophoresis showing a direct competition between supercoiled (S/C) or linear DNA binding to dodecameric Dps-1. Concentrations of dodecameric Dps-1 are indicated above the panel. All reactions containing dodecameric Dps- 1 contain $400 \mathrm{mM} \mathrm{NaCl}$ to avoid precipitation of the protein Complexed and free DNA are identified at the right.

would be consistent with a lower molecular mass assembly.

Dodecameric Dps-1 interacts with DNA; a modest retardation is seen at lower protein to DNA ratios, followed by formation of large aggregates that do not enter the gel (Figure 7(b)). DNA binding is seen whether or not a core is present; the experiments below are performed with apo-Dps-1. Aggregation of all available DNA is seen at $\sim 3.6$ pmol of dodecamer, corresponding to a density of one dodecamer per $\sim 43 \mathrm{bp}$. Identical protein to DNA molar ratios are seen to elicit complete aggregation using fivefold lower $(20 \mathrm{ng})$ or higher $(500 \mathrm{ng})$ concentrations of DNA, indicating that reactions are performed under (a)

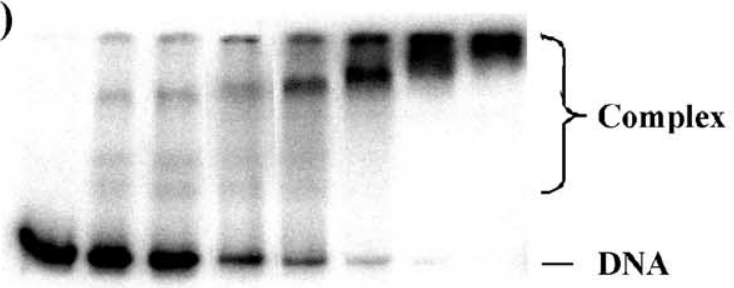

(b)

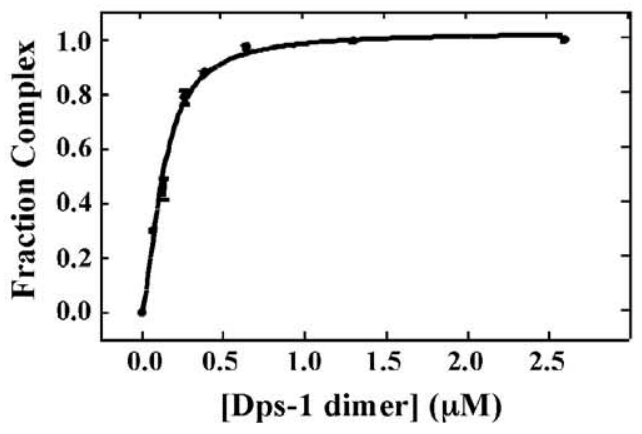

(c)

- Complex

- DNA

(d)

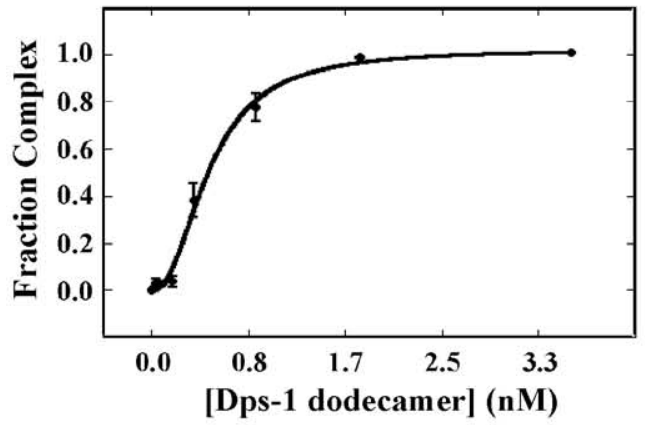

Figure 8. Differential DNA-binding by dimeric and dodecameric Dps-1. (a) Electrophoretic analysis of $76 \mathrm{bp}$ DNA titrated with dimeric Dps-1. Complexes and free DNA are indicated at the right. Protein concentrations are 0-2.5 $\mu \mathrm{M}$. (b) Binding isotherm for dimeric Dps-1 binding to 76 bp DNA $(n=3)$. When error bars are missing, they are smaller than the symbol size. The best fit to the data was obtained using the Hill equation $\left(R^{2}=0.9930 ; R^{2}=\right.$ 0.9756 for fits to a rectangular hyperbola). (c) Dodecameric Dps-1 binding to $26 \mathrm{bp}$ DNA, analyzed on $6 \%$ $(\mathrm{w} / \mathrm{v})$ polyacrylamide gel. (d) Binding isotherm for $26 \mathrm{bp}$ DNA titrated with dodecameric Dps- $1\left(R^{2}=0.9944\right.$ for fits to Hill equation (shown); $R^{2}=0.9508$ for fits to hyperbola). 
stoichiometric conditions ([DNA] $>K_{d}$ ). Since dimeric Dps-1 binds DNA, dodecameric Dps- 1 is expected to engage more than one DNA site, and aggregation is likely caused, at least in part, by each dodecamer engaging multiple DNA sites, suggesting interactions at a single site across $<21$ bp. While dimeric Dps-1 appears to exhibit positive cooperativity, binding preferentially to DNA already occupied by protein, resulting in a bimodal distribution between saturated and unbound DNA, dodecameric Dps-1 appears to favor binding to free DNA over already complexed DNA, leading to a gradually increasing retardation of the entire population of DNA as a relatively sharp band, until aggregation of DNA causes its retention in the well. This distribution of bound species could be interpreted as cooperative binding. However, quantification of complex formation in this assay is not possible, due in part to reduced staining of Dps-1-bound DNA with ethidium bromide (data not shown). In a direct competition between supercoiled and linear DNA, no preference is seen for either topological form (Figure 7(c)).

The Dps-1-DNA association was quantified using $26 \mathrm{bp}$ and $76 \mathrm{bp}$ DNA. Figure 8(a) shows $76 \mathrm{bp}$ DNA titrated with dimeric Dps-1, showing formation of multiple complexes. The best fit to the data was obtained using non-linear fits to the Hill equation, yielding $K_{\mathrm{d}}=1.3( \pm 0.2) \mu \mathrm{M}$ and a Hill coefficient, $n=1.6 \pm 0.1$, indicating positive cooperativity of binding (Figure 8(b)). With $26 \mathrm{bp}$ DNA, multiple complexes are also seen, and fits to the data yield $K_{\mathrm{d}}=1.3( \pm 0.2) \mu \mathrm{M}$ and $n=1.4 \pm 0.0$ (data not shown). For dodecameric Dps-1, complex formation is represented by a failure of bound DNA to enter the gel (Figure 8(c)). Half-maximal saturation is seen at $0.5( \pm 0.0) \mathrm{nM}$ dodecamer with $n=2.2 \pm 0.3$, also indicative of positive cooperativity of binding (Figure $8(\mathrm{~d})$ ). The greater affinity of dodecameric Dps-1 cannot be ascribed simply to the presence of multiple binding sites, but may be due to conformational changes or folding of the N-terminal domain associated with oligomerization.

Dps proteins have been reported to afford protection against DNA cleavage by hydroxyl radicals generated in $\mathrm{Fe}(\mathrm{II})$-mediated Fenton reactions. As shown in Figure 9(a), treatment of supercoiled DNA for five minutes with $150 \mu \mathrm{M}$ $\mathrm{Fe}\left(\mathrm{NH}_{4}\right)_{2}\left(\mathrm{SO}_{4}\right)_{2}$ and $10 \mathrm{mM} \mathrm{H} \mathrm{H}_{2} \mathrm{O}_{2}$ leads to its complete degradation, while significant protection is seen in the presence of dimeric Dps-1, where approximately $50 \%$ of the DNA remains supercoiled and the remainder is relaxed (nicked; lane 4). Direct association of Dps-1 with the DNA is demonstrated also by its ability to protect DNA from nuclease digestion; under conditions where DNase I degrades the DNA completely, the presence of dimeric Dps-1 leaves $\sim 30 \%$ of the DNA intact, with the remainder of the DNA nicked or linearized (lane 8).

Notably, dodecameric Dps-1 does not protect DNA against degradation (Figure 9(b)). Partial cleavage of supercoiled DNA with hydroxyl (a)
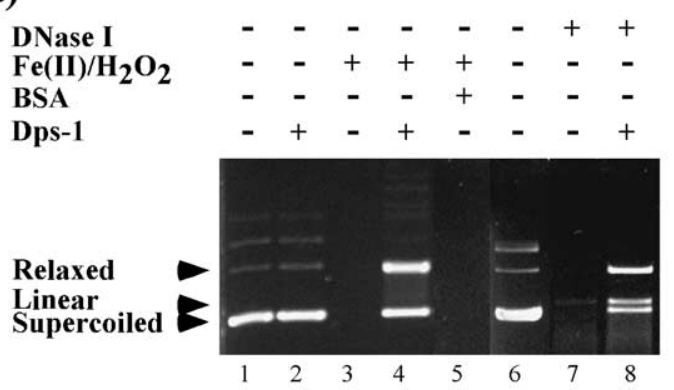

(b)
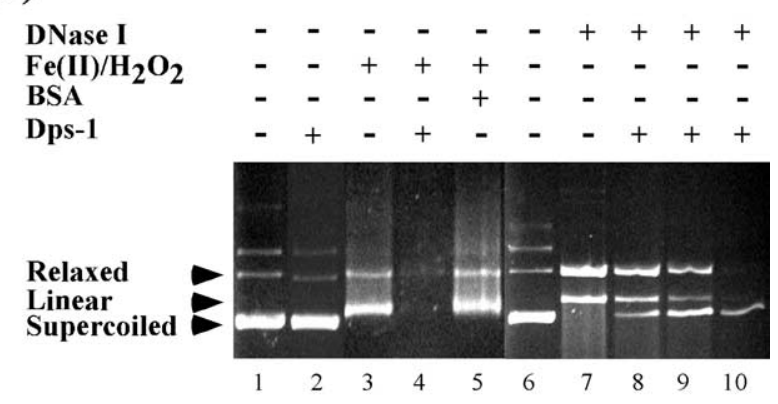

(c)

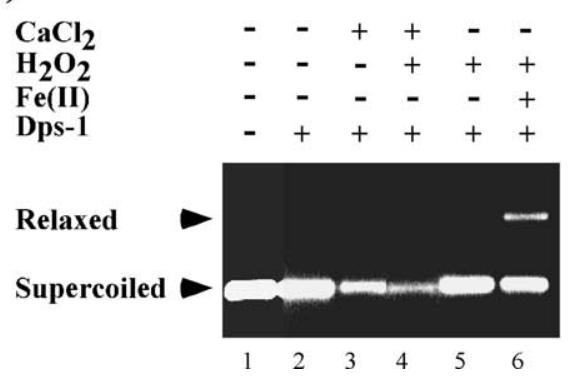

Figure 9. Protection of DNA by Dps-1. Cleavage of $100 \mathrm{ng}$ of supercoiled DNA by hydroxyl radical (Fe(II) $/ \mathrm{H}_{2} \mathrm{O}_{2}$ ) or DNase I is denoted above the panels, along with the presence of bovine serum albumin (BSA), dimeric Dps-1 (43 pmol of dimer in (a)) or dodecameric Dps-1 (3.6 pmol of dodecamer in (b)). (c) Effect of $\mathrm{Ca}^{2+}$ on DNA degradation. Reactions contain $100 \mathrm{ng}$ of supercoiled DNA, without (lane 1) or with 4.3 pmol of dodecameric Dps-1 (lanes 2-6). Reactions in lanes 3 and 4 contain $5 \mathrm{mM} \mathrm{CaCl} 2 . \mathrm{H}_{2} \mathrm{O}_{2}$ and $\mathrm{Fe}(\mathrm{II})$ are supplemented as indicated above the panel.

radicals leads to formation of linear and relaxed species, but complete degradation of the DNA is seen in the presence of Dps-1 (lanes 3 and 4). This is consistent with the formation of $\mathrm{H}_{2} \mathrm{O}_{2}$ as a product of the ferroxidase reaction at the ferroxidase center causing increased production of hydroxyl radicals upon reaction with $\mathrm{Fe}(\mathrm{II})$. While some retention of supercoiled DNA is observed upon incubation of DNA with Dps-1 and DNase I, suggesting protection from DNase I cleavage, higher concentrations of Dps-1 result in more extensive DNA degradation (lanes 7-9), perhaps due to divalent cationmediated release of Fe(II) from Dps-1. Given the $\mathrm{Ca}^{2+}$-induced loss of $\mathrm{Fe}(\mathrm{III})$-absorbance from the 
Dps- 1 core, we assayed the affect of $\mathrm{Ca}^{2+}$ on Dps-1mediated protection of DNA from oxidative damage (Figure 9(c)). In the presence of Dps-1, $5 \mathrm{mM} \mathrm{Ca}^{2+}$ promotes oxidative cleavage of DNA (lane 3), and the addition of $\mathrm{H}_{2} \mathrm{O}_{2}$ to the reaction causes an increase in DNA degradation (lane 4); relatively little effect of $\mathrm{H}_{2} \mathrm{O}_{2}$ is observed in the absence of $\mathrm{Ca}^{2+}$ (lane 5), suggesting that $\mathrm{Fe}(\mathrm{II})$ is being released from Dps-1 in response to $\mathrm{Ca}^{2+}$ and is subsequently available to react with $\mathrm{H}_{2} \mathrm{O}_{2}$ to generate damaging hydroxyl radicals through the Fenton reaction.

\section{Discussion}

\section{Structural considerations}

Listeria ferritin, crystallized in the presence of iron, revealed 12 electron density peaks (one per monomer) assigned to iron ions at the dimer interfaces. ${ }^{15}$ Even after reduction with dithionite, the protein still contained one $\mathrm{Fe}^{2+} /$ monomer. Similarly, divalent cations may form part of the dimer interface in Dps-1. While Dps-1 can exist as a dimer in solution under reducing, low-salt conditions, an effectively irreversible assembly into a dodecamer is induced on exposure to higher ionic strength. As shown also for Listeria ferritin, dodecameric Dps-1 dissociates into dimers only at $\mathrm{pH}<2$, while denaturing. ${ }^{24}$

The four-helix bundle fold of Dps homologs is reflected in a high content of $\alpha$-helix in the structures analyzed. The Dps proteins from E. coli and M. smegmatis, and Hp-NAP from H. pylori, are $68 \%, 63 \%$, and $78 \% \alpha$-helical in composition, respectively. The far-UV CD spectrum of Dps-1 is consistent with a protein of high $\alpha$-helical content (Figure 3(a)). The high thermal stability observed for Dps-1 is characteristic of four-helix bundle folds, such as the central four-helix bundle of GrpE, which has a $T_{\mathrm{m}}$ of $75^{\circ} \mathrm{C}$ (Figure 3(b)). ${ }^{31}$ Ellipticity measurements of the Dps homolog, Hp-NAP, were reported to show no thermal denaturation up to $80^{\circ} \mathrm{C} .{ }^{18}$ The single thermal transition observed from ellipticity measurements of Dps-1 suggests that the distinctive $\mathrm{N}$-terminal extension of this protein does not form a separate structural domain. Whether the lower thermal stability of Dps-1 relative to $\mathrm{Hp}-\mathrm{NAP}$ is related to this N-terminal extension remains to be determined; however, the greater stability of Hp-NAP may be the result of evolutionary pressures to remain folded, despite the fluctuations in intracellular $\mathrm{pH}$ that are characteristic of the H. pylori lifecycle. ${ }^{32,33}$

\section{Ferroxidase activity of Dps-1}

In ferritin, iron deposition leads to the formation of a microcrystalline core that contains packed oxygen atoms, with iron atoms located such that they may be coordinated either octahedrally or tetrahedrally. ${ }^{34,35} \mathrm{Fe}(\mathrm{III})$ coordinated tetrahedrally with oxygen has a typical absorption band around $380 \mathrm{~nm}$, while Fe(III) coordinated octahedrally with oxygen has absorption bands at $407 \mathrm{~nm}$ and $550 \mathrm{~nm} .{ }^{36}$ We detected two distinct populations of dodecameric Dps-1 with significant absorbance above $300 \mathrm{~nm}$. One population has a predominant absorbance at $380 \mathrm{~nm}$ (Figure 4(a), broken line), suggesting tetrahedrally coordinated iron, as reported for E. coli Dps, ${ }^{6}$ but a second population is characterized by significant absorbance throughout the wavelength range, perhaps corresponding to different coordination of $\mathrm{Fe}(\mathrm{III})$ within the core. As seen for other ferritins, the microcrystalline iron core is mobilizable after reduction (Figure 5). Although the iron reduction and release process is complex, involving for example diffusion of dithionite through the protein and electron transfer from dithionite to $\mathrm{Fe}(\mathrm{III})$, the apparent biphasic mode has been ascribed to the reduction of two populations of iron atoms, perhaps corresponding to atoms in the core and atoms directly associated with the interior of the protein shell. 6,37

Mineralization of Listeria ferritin was shown to proceed in three phases. After rapid binding of $\mathrm{Fe}(\mathrm{II})$ to the ferroxidase center, the slowest phase corresponds to the ferroxidation reaction at this center, with the phase 3 mineralization reaction proceeding faster than phase $2 .^{38}$ By comparison, the progress curves of Fe(II) oxidation by Dps-1 are complex, and are linked to the presence of bound $\mathrm{Ca}^{2+}$. While the number of iron-binding sites at the ferroxidase centers is constant, the number of sites within the mineral core would increase with surface area, thus competing more effectively for iron ions. This effect has been shown to lead to an all-or-none distribution of iron among ferritin molecules, and it is consistent with a faster rate of iron oxidation at the mineral surface. ${ }^{27}$ Notably, the slow rate of ferroxidation in the presence of molecular oxygen characteristic of Dps-1 would result in a slow nucleation of the mineral core, leading to a ratedetermining slow phase following the initial binding of $\mathrm{Fe}(\mathrm{II})$ at the ferroxidase center. Once the mineral core reaches a critical mass, effective surface oxidation of Fe(II) may occur, resulting in a faster rate of $\mathrm{Fe}(\mathrm{II})$ oxidation preceding the final plateau (Figure 6(c)). Consistent with this interpretation, dimeric Dps-1 does not display this second fast phase (Figure 6(d)).

Since Fe(II) oxidation and nucleation of the mineral core occur at the ferroxidase center and on the inner surface of the protein cavity, respectively, and since a mineralized iron core can perform surface oxidation of $\mathrm{Fe}(\mathrm{II})$, both $\mathrm{Fe}(\mathrm{II})$ and $\mathrm{Fe}(\mathrm{III})$ must be able to move between these sites. The initial oxidation step is controlled by the geometry of the ferroxidase center. Our data suggest that initial rates of iron oxidation are faster when iron is already bound at the ferroxidase center, while bound calcium ions result in a significantly slower initial rate of ferroxidation, perhaps corresponding to slow conformational changes at the ferroxidase center needed for iron binding. Notably, dodecameric 
Dps-1 characterized by a mixture of coordination states of $\mathrm{Fe}(\mathrm{III})$ responds to the addition of $\mathrm{Ca}^{2+}$ by a reduced absorbance of $\mathrm{Fe}(\mathrm{III})$-species, including iron in the mineralized core. Residues corresponding to D98 and D109 of Dps-1 were shown recently to coordinate $\mathrm{Ca}^{2+}$ in the structure of S. suis Dps. ${ }^{28}$ These residues adopt different conformations compared to iron-loaded structures, suggesting that their involvement in iron binding would require a conformational change, and that binding of iron and calcium ions may be mutually exclusive. Noting the slow rate of Fe(II) oxidation following binding of $\mathrm{Ca}^{2+}$ and the transition to a more complex progress curve upon prolonged incubation in the presence of $\mathrm{Ca}^{2+}$ (Figure 6(c)), we propose that the binding of $\mathrm{Ca}^{2+}$ also attenuates the movement of iron into the protein core, thereby controlling the effective rate of iron oxidation and sequestration. We note that $\mathrm{Zn}^{2+}$, which is seen to block ferroxidation both by Dps-1 and other Dps homologs, does not reproduce the effect of $\mathrm{Ca}^{2+}$, suggesting that $\mathrm{Ca}^{2+}$ and $\mathrm{Zn}^{2+}$ do not bind to the same site, and consistent with the reported ability of $\mathrm{Zn}^{2+}$ to compete with iron for binding to the ferroxidase site. $^{29}$

\section{DNA-binding and protection by Dps-1}

For M. smegmatis Dps, a dodecameric assembly forms only after several hours incubation at $37^{\circ} \mathrm{C} .{ }^{20}$ In contrast, protein stored at $4{ }^{\circ} \mathrm{C}$ adopts a lower oligomeric state, presumed to be a trimer (although we note that, since it was reported to be a ferroxidizing species, it would likely be a dimer). However, the lower molecular mass M. smegmatis Dps species fails to bind DNA. Likewise, E. coli Dps was presumed to bind DNA only as a dodecamer. ${ }^{14}$ In contrast, we have observed DNA-binding under conditions that disfavor oligomerization, thus showing that oligomerization of Dps-1 is not required for DNA-binding. We assessed this possibility by crosslinking of dimeric Dps-1 in the presence of DNA and observed no difference in the pattern of crosslinked species. While this observation does not rigorously rule out the possibility that other oligomeric assemblies may be responsible for, or contribute to, DNA-binding, it does support the interpretation that dimeric and dodecameric Dps-1, respectively, correspond to the DNA-binding species. This interpretation is consistent with the observation that DNA-binding by the two Dps-1 preparations is clearly different, ruling out the possibility that only one oligomeric assembly is capable of binding DNA, regardless of the oligomerization state of unbound protein. Secondly, the dodecamer is an exceedingly stable species that does not appear to dissociate once formed and which shows no evidence of existing in an equilibrium with dimeric or other oligomeric assemblies.

The different modes of DNA contact exhibited by dimeric and dodecameric Dps-1 suggests differential functions, perhaps corresponding to gene-regulatory functions associated with dimeric Dps-1, while dodecameric Dps-1 may be required for chromosome organization. Notably, E. coli Dps, which is upregulated under stress, induces the formation of toroidal assemblies with the genomic DNA. ${ }^{7-9}$ It is therefore tempting to speculate on a role for D. radiodurans Dps-1 in assembly of the toroidal structures characteristic of the D. radiodurans genomic DNA. ${ }^{39}$ Remarkably, dodecameric Dps-1 does not share the ability to protect DNA from $\cdot \mathrm{OH}$-mediated degradation that is characteristic of other Dps homologs. Instead, its primary role may be in the $\mathrm{Ca}^{2+}$-mediated regulation of iron homeostasis.

\section{Materials and Methods}

\section{Cloning and purification of Dps-1}

The gene encoding D. radiodurans Dps-1 (DR2263) was amplified from $D$. radiodurans $\mathrm{R} 1$ genomic DNA using a forward primer modified to introduce an NdeI site (5'GTAGGGTGCGCATATGACGAAG-3') and a reverse primer modified to introduce an EcoRI site $\left(5^{\prime}\right.$ GGCATGGTGAATTCCCCTTCTCC-3'; restriction sites underlined) and cloned into $\mathrm{NdeI} /$ EcoRI-digested pET5a. The integrity of the construct was confirmed by sequencing. The resulting plasmid was used to transform E. coli BL21(DE3)pLysS. Overexpression was induced with $1 \mathrm{mM}$ isopropyl-1-thio- $\beta$-D-galactopyranoside (IPTG). Cells were lysed as described, ${ }^{40}$ and cell lysates were dialyzed against buffer A ( $20 \mathrm{mM}$ Tris- $\mathrm{HCl}(\mathrm{pH} 8.0)$, $50 \mathrm{mM} \mathrm{KCl}, 5 \%$ (v/v) glycerol, $1 \mathrm{mM}$ EDTA, $0.2 \mathrm{M}$ phenylmethylsulfonyl fluoride (PMSF)) and applied to a heparin-agarose column equilibrated in buffer $\mathrm{A}$. The protein was eluted with a linear gradient from $50 \mathrm{mM}$ to $1 \mathrm{M} \mathrm{KCl}$ in buffer $\mathrm{A}$. The addition of $\beta$-mercaptoethanol was avoided, as its presence $(5 \mathrm{mM})$ resulted in elution of Dps-1, which contains a single cysteine residue, in earlier fractions along with numerous impurities. Protein eluted from heparin-agarose under reducing conditions was therefore pooled and applied to a DEAE-Sepharose column equilibrated in buffer A containing $5 \mathrm{mM}$ $\beta$-mercaptoethanol and eluted with a linear gradient from $50 \mathrm{mM}$ to $1 \mathrm{M} \mathrm{KCl}$ in buffer A with $5 \mathrm{mM}$ $\beta$-mercaptoethanol. Dps-1 purified by either procedure was judged $>95 \%$ pure based on SDS-polyacrylamide gels stained with Coomassie brilliant blue. Protein concentrations were determined by staining of SDSpolyacrylamide gels with Coomassie brilliant blue, using bovine serum albumin (BSA) as a standard.

\section{Protein crosslinking}

Proteins were crosslinked in a total volume of $10 \mu \mathrm{l}$ of $10 \mathrm{mM}$ bicine (pH 8.5), $50-500 \mathrm{mM} \mathrm{NaCl}$ with $0.1 \%(\mathrm{v} / \mathrm{v})$ glutaraldehyde at room temperature for 30 minutes. Reactions were terminated by addition of an equal volume of Laemmli sample buffer, and the crosslinked products were analyzed by SDS-PAGE. Apparent molecular masses of crosslinked species were determined using a plot of distance migrated by molecular mass markers as a function of molecular mass. 


\section{Circular dichroism (CD) spectroscopy}

CD spectroscopy was performed on an AVIV 202 CD spectrophotometer. All protein samples were equilibrated at room temperature for 20 minutes before measurements were collected using a sealed quartz cuvette with a $1 \mathrm{~cm}$ pathlength. For the wavelength scan, dodecameric Dps-1 was diluted to $25 \mu \mathrm{g} / \mathrm{ml}$ in scan solution A $(20 \mathrm{mM}$ potassium phosphate $(\mathrm{pH} 7), 0.4 \mathrm{M} \mathrm{KCl}, 10 \%$ (v/v) glycerol, $0.05 \%$ (v/v) Tween-20), and ellipticity measurements were collected at $25^{\circ} \mathrm{C}$ in $1 \mathrm{~nm}$ steps.

For thermal denaturation, dodecameric Dps-1 was diluted to $0.2 \mathrm{mg} / \mathrm{ml}$ in scan solution $\mathrm{B}(50 \mathrm{mM}$ potassium phosphate ( $\mathrm{pH} \mathrm{7}), 200 \mathrm{mM} \mathrm{KCl})$. Ellipticity measurements were recorded from $225-219 \mathrm{~nm}(1 \mathrm{~nm}$ steps) over the temperature range $25-100^{\circ} \mathrm{C}$, with steps of $3^{\circ} \mathrm{C}\left(25-55^{\circ} \mathrm{C}\right.$ and $\left.88-100{ }^{\circ} \mathrm{C}\right)$ or $1.5^{\circ} \mathrm{C}\left(55-88^{\circ} \mathrm{C}\right)$. Each sample also underwent a reverse scan from $97-10^{\circ} \mathrm{C}$. Thermal equilibration time after each temperature step was three minutes, with stirring. Wavelength scans from 240-200 nm were performed at 25 and $100{ }^{\circ} \mathrm{C}$, in the forward scan, to verify the native and denatured states, and at $10{ }^{\circ} \mathrm{C}$ during the reverse scan. In a separate experiment, the denatured Dps- 1 was cooled from $100{ }^{\circ} \mathrm{C}$ by exposing the heated sample directly to room temperature and allowing it to equilibrate overnight before monitoring secondary structure. Dps-1 unfolding was analyzed using CD signals from $224-220 \mathrm{~nm}$. The thermal denaturation curve for each wavelength was fit to a modified form of the van't Hoff equation, which assumes a two-state model for protein unfolding. ${ }^{41}$ The $T_{\mathrm{m}}$ and $\Delta H_{\mathrm{vH}}$ of Dps-1 unfolding are reported as the mean \pm standard deviation.

\section{Iron incorporation by Dps-1}

Iron incorporation or reduction was measured spectrophotometrically using a Beckman DU-64 spectrophotometer equipped with a Kinetics Soft-Pac module. Iron-loaded dodecameric Dps-1 was prepared by incubation of $0.3 \mathrm{mg} / \mathrm{ml}$ of apo-Dps- 1 with $65 \mu \mathrm{M}$ ferrous ammonium sulfate for one hour, followed by purification by gel-filtration on Bio-Spin 6 columns (BioRad). Kinetics of iron reduction was measured at $520 \mathrm{~nm}$ using $0.1 \mathrm{mg} / \mathrm{ml}$ of iron-loaded Dps-1 in $20 \mathrm{mM}$ Mops (pH 7.0), $400 \mathrm{mM} \mathrm{NaCl}, 1 \mathrm{mM}$ 2,2'-bipyridyl. Reactions were initiated by addition of freshly prepared sodium dithionite to $0.3 \%(\mathrm{w} / \mathrm{v})$ final concentration. Data were fit to a sum of two exponentials. The apo-Dps-1 was prepared by diluting Dps to $0.4 \mathrm{mg} / \mathrm{ml}$ in $20 \mathrm{mM}$ Mops (pH 7.0), $400 \mathrm{mM} \mathrm{NaCl}$ followed by incubation for one

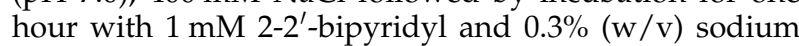
dithionite and purification by gel-filtration on Bio-Spin 6 columns. The kinetics of iron incorporation was measured at $310 \mathrm{~nm}$; Dps- 1 was diluted to $0.2 \mathrm{mg} / \mathrm{ml}$ in $20 \mathrm{mM}$ Mops (pH 7.0), $400 \mathrm{mM} \mathrm{NaCl}$. Solutions of ferrous ammonium sulfate were prepared immediately before each experiment. The $\mathrm{Ca}^{2+}$-mediated modulation of absorbing iron species was measured at $380 \mathrm{~nm}$ after addition of the indicated concentration of $\mathrm{CaCl}_{2}$ to $0.2 \mathrm{mg} / \mathrm{ml}$ of dodecameric Dps-1 in $20 \mathrm{mM}$ Mops (pH 7.0), $400 \mathrm{mM} \mathrm{NaCl}$. Ferroxidation by dimeric Dps-1 was recorded in $20 \mathrm{mM}$ Mops (pH 7.0), $100 \mathrm{mM} \mathrm{NaCl}$. The kinetic data were further analyzed using KaleidaGraph.

\section{Electrophoretic mobility-shift assays}

Supercoiled or linearized pGEM5 (100 ng, corresponding to $52 \mathrm{fmol}$ of plasmid) was mixed with Dps- 1 in $10 \mu \mathrm{l}$ of binding buffer $(20 \mathrm{mM}$ Tris- $\mathrm{HCl}(\mathrm{pH}$ 8.0), $100 \mathrm{mM} \mathrm{KCl}, 0.1 \mathrm{mM}$ EDTA, $0.1 \mathrm{mM}$ dithiothreitol, $0.05 \%$ (w/v) Brij58, $10 \mu \mathrm{g} / \mathrm{ml}$ of BSA, $5 \%$ glycerol), unless specified otherwise. After incubation at room temperature for 30 minutes, the entire reaction was loaded onto a $1.0 \%(\mathrm{w} / \mathrm{v})$ agarose gel in $0.5 \times \mathrm{TBE}(45 \mathrm{mM}$ Tris-borate ( $\mathrm{pH}$ 8.3), $1 \mathrm{mM}$ EDTA). No difference in complex formation was seen for incubation times of 15-60 minutes. DNA was visualized by staining with ethidium bromide following electrophoresis.

Oligonucleotides used to generate short DNA constructs were purchased and purified by denaturing polyacrylamide gel electrophoresis. The sequences of $26 \mathrm{bp}$ and $76 \mathrm{bp}$ DNA (average $\mathrm{G}+\mathrm{C}$-content) are available on request. The top strand was ${ }^{32} \mathrm{P}$-labeled at the $5^{\prime}$-end with phage T4 polynucleotide kinase. Equimolar amounts of complementary oligonucleotides were mixed, heated to $90{ }^{\circ} \mathrm{C}$ and cooled slowly to $4{ }^{\circ} \mathrm{C}$ to form duplex DNA.

Electrophoretic mobility-shift assays were performed using $10 \%(\mathrm{w} / \mathrm{v})$ polyacrylamide gels $(39: 1(\mathrm{w} / \mathrm{w})$ acrylamide to bisacrylamide) in TBE, unless noted otherwise. ${ }^{42}$ Gels were run for 30 minutes at $20 \mathrm{~mA}$ at room temperature before loading the samples with the power on. DNA and protein were mixed in binding buffer (containing $50 \mathrm{mM} \mathrm{NaCl}$ for dimeric Dps-1 and $500 \mathrm{mM}$ $\mathrm{NaCl}$ for dodecameric Dps-1), and each sample contained $50 \mathrm{fmol}$ (for dimeric Dps-1) or $2.5 \mathrm{fmol}$ (for dodecamer) of DNA in a total reaction volume of $10 \mu \mathrm{l}$. After electrophoresis, gels were dried and protein-DNA complexes and free DNA were quantified by phosphoimaging, using software supplied by the manufacturer (ImageQuant 1.1). Data were fit to:

$$
f=f_{\max }[D p s-1]^{n} /\left(K_{\mathrm{d}}+[D p s-1]^{n}\right)
$$

where [Dps-1] is the protein concentration, $f$ is fractional saturation, $K_{\mathrm{d}}$ is the apparent equilibrium dissociation constant, and $n$ is the Hill coefficient. Fits were performed using the program KaleidaGraph, and quality of the fits was evaluated by visual inspection, $\chi^{2}$ values and correlation coefficients. All experiments were carried out at least in triplicate.

\section{DNA protection assay}

Protection of DNA from oxidative damage was measured using supercoiled pGEM5. DNA (100 ng) was incubated for 30 minutes with Dps- 1 in a $10 \mu \mathrm{l}$ volume of $20 \mathrm{mM}$ Tris- $\mathrm{HCl}$ (pH 8.0), $100 \mathrm{mM} \mathrm{KCl}$. Fe $\left(\mathrm{NH}_{4}\right)_{2}\left(\mathrm{SO}_{4}\right)_{2}$ (to $150 \mu \mathrm{M}$ ) and $\mathrm{H}_{2} \mathrm{O}_{2}$ (to $10 \mathrm{mM}$ ) were added unless specified otherwise, and the reaction allowed to proceed for five minutes at room temperature. Reactions were terminated with $0.8 \%(\mathrm{w} / \mathrm{v})$ SDS and $2.5 \%$ glycerol, and the entire reaction loaded onto a $1 \%$ agarose gel in $0.5 \times$ TBE. For protection against DNase I-mediated cleavage, reactions were assembled as above, and DNase I added in a buffer supplying $0.5 \mathrm{mM} \mathrm{CaCl}{ }_{2}$ and $0.5 \mathrm{mM} \mathrm{MgCl}_{2}$ following incubation at room temperature for 30 minutes. DNase I digestions were terminated with $1.2 \%$ SDS, $10 \mathrm{mM}$ EDTA and 3.4\% glycerol after incubation at room temperature for five minutes and the entire reaction loaded on $1 \%$ agarose gels in $0.5 \times \mathrm{TBE}$. To monitor the affect of $\mathrm{CaCl}_{2}$ on Dps-1 mediated protection, DNA was incubated for 20 minutes with $4.3 \mathrm{pmol}$ of dodecameric Dps-1 in $10 \mu \mathrm{l}$ of $25 \mathrm{mM}$ Tris- $\mathrm{HCl}$ (pH 8.0), $200 \mathrm{mM} \mathrm{NaCl}$; $\mathrm{CaCl}_{2}$ was subsequently supplied at the concentration specified. Where indicated, $\mathrm{Fe}\left(\mathrm{NH}_{4}\right)_{2}\left(\mathrm{SO}_{4}\right)_{2}$ and $\mathrm{H}_{2} \mathrm{O}_{2}$ were supplied at final concentrations of $10 \mu \mathrm{M}$ and $5 \mathrm{mM}$, 
respectively, and the reaction allowed to proceed at room temperature for ten minutes. Reactions were terminated with $2 \%$ glycerol and $0.7 \%$ SDS, and the entire reaction loaded onto a $1 \%$ agarose gel in $0.5 \times$ TBE. This assay was performed in triplicate with separate preparations of Dps-1. Gels were stained with ethidium bromide after electrophoresis.

\section{Acknowledgements}

We thank Y.-H. Lee for helpful discussions and for communicating structural information on Dps-1 prior to publication. This work was supported, in part, by the National Science Foundation (MCB0414875 to A.G.).

\section{References}

1. Crichton, R. R., Wilmet, S., Legssyer, R. \& Ward, R. J. (2002). Molecular and cellular mechanisms of iron homeostasis and toxicity in mammalian cells. J. Inorg. Biochem. 91, 9-18.

2. Farr, S. B. \& Kogoma, T. (1991). Oxidative stress responses in Escherichia coli and Salmonella typhimurium. Microbiol. Rev. 55, 561-585.

3. Almirón, M., Link, A. J., Furlong, D. \& Kolter, R. (1992). A novel DNA-binding protein with regulatory and protective roles in starved Escherichia coli. Genes Dev. 6, 2646-2654

4. Martinez, A. \& Kolter, R. (1997). Protection of DNA during oxidative stress by the nonspecific DNAbinding protein Dps. J. Bacteriol. 179, 5188-5194.

5. Zhao, G., Ceci, P., Ilari, A., Giangiacomo, L., Laue, T. M., Chiancone, E. \& Chasteen, N. D. (2002). Iron and hydrogen peroxide detoxification properties of DNA-binding protein from starved cells. A ferritinlike DNA-binding protein of Escherichia coli. J. Biol. Chem. 277, 27689-27696.

6. Ilari, A., Ceci, P., Ferrari, D., Rossi, G. L. \& Chiancone, E. (2002). Iron incorporation into Escherichia coli Dps gives rise to a ferritin-like microcrystalline core. J. Biol. Chem. 277, 37619-37623.

7. Lomovskaya, O. L., Kidwell, J. P. \& Matin, A. (1994). Characterization of the sigma 38-dependent expression of a core Escherichia coli starvation gene, pexB. J. Bacteriol. 176, 3928-3935.

8. Altuvia, S., Almirón, M., Huisman, G., Kolter, R. \& Storz, G. (1994). The dps promoter is activated by OxyR during growth and by IHF and sigma $S$ in stationary phase. Mol. Microbiol. 13, 265-272.

9. Frenkiel-Krispin, D., Ben-Avraham, I., Englander, J., Shimoni, E., Wolf, S. G. \& Minsky, A. (2004). Nucleoid restructuring in stationary-state bacteria. Mol. Microbiol. 51, 395-405.

10. Harrison, P. M. \& Arosio, P. (1996). The ferritins: molecular properties, iron storage function and cellular regulation. Biochim. Biophys. Acta, 1275, 161-203.

11. Boyd, D., Vecoli, C., Belcher, D. M., Jain, S. K. \& Drysdale, J. W. (1985). Structural and functional relationships of human ferritin $\mathrm{H}$ and $\mathrm{L}$ chains deduced from cDNA clones. J. Biol. Chem. 260, 11755-11761.

12. Hempstead, P. D., Yewdall, S. J., Fernie, A. R., Lawson, D. M., Artymiuk, P. J., Rice, D. W. et al. (1997).
Comparison of the three-dimensional structures of recombinant human $\mathrm{H}$ and horse $\mathrm{L}$ ferritins at high resolution. J. Mol. Biol. 268, 424-448.

13. Bozzi, M., Mignogna, G., Stefanini, S., Barra, D., Longhi, C., Valenti, P. \& Chiancone, E. (1997). A novel non-heme iron-binding ferritin related to the DNAbinding proteins of the Dps family in Listeria innocua. J. Biol. Chem. 272, 3259-3265.

14. Grant, R. A., Filman, D. J., Finkel, S. E., Kolter, R. \& Hogle, J. M. (1998). The crystal structure of Dps, a ferritin homolog that binds and protects DNA. Nature Struct. Biol. 5, 294-303.

15. Ilari, A., Stefanini, S., Chiancone, E. \& Tsernoglou, D. (2000). The dodecameric ferritin from Listeria innocua contains a novel intersubunit iron-binding site. Nature Struct. Biol. 7, 38-43.

16. Papinutto, E., Dundon, W. G., Pitulis, N., Battistutta, R., Montecucco, C. \& Zanotti, G. (2002). Structure of two iron-binding proteins from Bacillus anthracis. J. Biol. Chem. 277, 15093-15098.

17. Zanotti, G., Papinutto, E., Dundon, W., Battistutta, R., Seveso, M., Giudice, G. et al. (2002). Structure of the neutrophil-activating protein from Helicobacter pylori. J. Mol. Biol. 323, 125-130.

18. Tonello, F., Dundon, W. G., Satin, B., Molinari, M., Tognon, G., Grandi, G. et al. (1999). The Helicobacter pylori neutrophil-activating protein is an iron-binding protein with dodecameric structure. Mol. Microbiol. 34, 238-246.

19. Ceci, P., Ilari, A., Falvo, E. \& Chiancone, E. (2003). The Dps protein of Agrobacterium tumefaciens does not bind to DNA but protects it toward oxidative cleavage: X-ray crystal structure, iron binding, and hydroxyl-radical scavenging properties. J. Biol. Chem. 278, 20319-20326.

20. Gupta, S. \& Chatterji, D. (2003). Bimodal protection of DNA by Mycobacterium smegmatis DNA-binding protein from stationary phase cells. J. Biol. Chem. 278, 5235-5241.

21. Battista, J. R. (1997). Against all odds: the survival strategies of Deinococcus radiodurans. Annu. Rev. Microbiol. 51, 203-224.

22. Wilson, D. M., III, Sofinowski, T. M. \& McNeill, D. R. (2003). Repair mechanisms for oxidative DNA damage. Front Biosci. 8, d963-d981.

23. White, O., Eisen, J. A., Heidelberg, J. F., Hickey, E. K., Peterson, J. D., Dodson, R. J. et al. (1999). Genome sequence of the radioresistant bacterium Deinococcus radiodurans $\mathrm{R} 1$. Science, 286, 1571-1577.

24. Chiaraluce, R., Consalvi, V., Cavallo, S., Ilari, A., Stefanini, S. \& Chiancone, E. (2000). The unusual dodecameric ferritin from Listeria innocua dissociates below pH 2.0. Eur. J. Biochem. 267, 5733-5741.

25. Woody, R. W. (1995). Circular dichroism. Methods Enzymol. 246, 34-71.

26. Mao, D. \& Wallace, B. A. (1984). Differential light scattering and absorption flattening optical effects are minimal in the circular dichroism spectra of small unilamellar vesicles. Biochemistry, 23, 2667-2673.

27. Macara, I. G., Hoy, T. G. \& Harrison, P. M. (1972). The formation of ferritin from apoferritin. Kinetics and mechanism of iron uptake. Biochem. J. 126, 151-162.

28. Kauko, A., Haataja, S., Pulliainen, A. T., Finne, J. \& Papageorgiou, A. C. (2004). Crystal structure of Streptococcus suis Dps-like peroxide resistance protein Dpr: implications for iron incorporation. J. Mol. Biol. 338, 547-558.

29. Stefanini, S., Cavallo, S., Montagnini, B. \& Chiancone, 
E. (1999). Incorporation of iron by the unusual dodecameric ferritin from Listeria innocua. Biochem. J. $338,71-75$.

30. Ellen, T. P. \& van Holde, K. E. (2004). Linker histone interaction shows divalent character with both supercoiled and linear DNA. Biochemistry, 43, 7867-7872.

31. Gelinas, A. D., Langsetmo, K., Toth, J., Bethoney, K. A., Stafford, W. F. \& Harrison, C. J. (2002). A structure-based interpretation of E. coli GrpE thermodynamic properties. J. Mol. Biol. 323, 131-142.

32. Wen, Y., Marcus, E. A., Matrubutham, U., Gleeson, M. A., Scott, D. R. \& Sachs, G. (2003). Acid-adaptive genes of Helicobacter pylori. Infect. Immun. 71, 5921-5939.

33. Chen, C., Ghosh, S. \& Grove, A. (2004). Substrate specificity of Helicobacter pylori histone-like HU protein is determined by insufficient stabilization of DNA flexure points. Biochem. J. 383, 343-351.

34. Massover, W. H. \& Cowley, J. M. (1973). The ultrastructure of ferritin macromolecules. The lattice structure of the core crystallites. Proc. Natl Acad. Sci. USA, 36, 3847-3851.

35. Chasteen, N. D. \& Harrison, P. M. (1999). Mineralization in ferritin: an efficient means of iron storage. J. Struct. Biol. 126, 182-194.

36. Webb, J. \& Gray, H. B. (1974). Spectral studies of the ferritin core and related iron (3) polymers. Biochim. Biophys. Acta, 351, 224-229.
37. Richards, T. D., Pitts, K. R. \& Watt, G. D. (1996). A kinetic study of iron release from Azotobacter vinelandii bacterial ferritin. J. Inorg. Biochem. 61, 1-13.

38. Yang, X., Chiancone, E., Stefanini, S., Ilari, A. \& Chasteen, N. D. (2000). Iron oxidation and hydrolysis reactions of a novel ferritin from Listeria innocua. Biochem. J. 349, 783-786.

39. Levin-Zaidman, S., Englander, J., Shimoni, E., Sharma, A. K., Minton, K. W. \& Minsky, A. (2003). Ringlike structure of the Deinococcus radiodurans genome: a key to radioresistance? Science, 299, 254-256.

40. Grove, A., Galeone, A., Mayol, L. \& Geiduschek, E. P. (1996). On the connection between inherent DNA flexure and preferred binding of hydroxymethyluracil-containing DNA by the type II DNA-binding protein TF1. J. Mol. Biol. 206, 196-206.

41. Ramsay, G. D. \& Eftink, M. R. (1994). Analysis of multidimensional spectroscopic data to monitor unfolding of proteins. Methods Enzymol. 240, 615-645.

42. Grove, A., Galeone, A., Mayol, L. \& Geiduschek, E. P. (1996). On the connection between inherent DNA flexure and preferred binding of hydroxymethyluracil-containing DNA by the type II DNA-binding protein TF1. J. Mol. Biol. 206, 196-206.

Edited by D. E. Draper

(Received 27 October 2004; received in revised form 18 January 2005; accepted 20 January 2005) 